\title{
PENGARUH DURASI DAN JEDA SISTEM IRIGASI TETES TERHADAP PERTUMBUHAN DAN HASIL SAWI PAKCOY (Brassica rapa L. ssp. chinensis)
}

\author{
Desy Enjellina $\mathbf{D}^{\mathbf{1}}$ \\ ${ }^{1}$ Agroteknologi, Fakultas Pertanian, Universitas Kristen Satya Wacana, Indonesia \\ E-Mail: 512017002@student.uksw.edu
}

\begin{abstract}
ABSTRAK
Pengaruh Durasi Dan Jeda Sistem Irigasi Tetes Terhadap Pertumbuhan Dan Hasil Sawi Pakcoy (Brassica rapa L. Ssp. Chinensis). Ketersediaan sumber air yang semakin berkurang dan tidak menentu akibat perubahan iklim yang disebabkan oleh pemanasan global, mengakibatkan perlunya suatu teknologi yang memungkinkan untuk mengatur jumlah air yang sesuai kebutuhan tanaman dan interval penyiraman tanaman yang tepat, sehingga ketersediaan air dapat terjaga pada musim kemarau dan pertumbuhan serta produktivitas tanaman juga menjadi optimal. Pengaturan jumlah air yang diberikan sesuai dengan kebutuhan tanaman dan interval penyiraman dikarenakan bidang pertanian merupakan faktor yang sangat membutuhkan air dan sangat boros untuk penggunaan air. Durasi ialah lamanya penyiraman yang diberikan per hari dan jeda ialah lamanya penyiraman pada pagi, siang dan sore. Tujuan penelitian untuk mengetahui pengaruh durasi dan jeda sistem irigasi tetes terhadap pertumbuhan dan hasil sawi pakcoy dan untuk mengetahui durasi dan jeda sistem irigasi tetes yang efisien dalam penggunaan air pada tanaman sawi pakcoy. Penelitian menggunakan Rancangan Acak Kelompok (RAK). Penelitian ini terdiri dari 6 perlakuan. Setiap perlakuan diulang sebanyak 4 kali. Perlakuan 3 dengan durasi 90 menit dan jeda pemberian air pagi dari 06:00-06:40, siang 13:00-13:10 dan sore 17:00-17:40 memberi pengaruh yang berbeda nyata terhadap pertumbuhan dan hasil tanaman sawi pakcoy dengan rata-rata tinggi tanaman tertinggi yaitu $30,21 \mathrm{~cm}$ dan jumlah daun dengan rata-rata 14,75 helai dan durasi dan jeda sistem irigasi tetes yang efisien dalam penggunaan air pada tanaman sawi pakcoy ialah perlakuan 3 dengan durasi 90 menit dan jeda pemberian air pagi dari 06:00-06:40, siang 13:00-13:10 dan sore 17:00-17:40.
\end{abstract}

Kata Kunci : Irigasi Tetes, Kebutuhan Air Tanaman, Pengaturan Durasi dan Jeda.

\begin{abstract}
Effect of Duration and Interval of Drip Irrigation System on Growth and Yield of Pakcoy Mustard (Brassica rapa L. Ssp. Chinensis). The availability of water sources that are decreasing and erratic due to climate change caused by global warming, requires a technology that allows to regulate the amount of water according to the needs of plants and the right interval of watering plants, so that the availability of water can be maintained in the dry season and plant growth also be optimal. Setting the amount of water given according to plant needs and watering intervals because agriculture is a factor that really needs water and is very wasteful for water use. Duration is the length of watering given per day and the interval is the length of watering in the morning, afternoon and evening. The aims of the study were to determine the effect of the duration and interval of the drip irrigation system on the growth and yield of mustard pakcoy and to determine the duration and interval of the efficient drip irrigation system in water use in mustard pakcoy. The study used a Randomized Block Design (RAK). This study consisted of 6 treatments. Each treatment was repeated 4 times. Treatment 3 with a duration of 90 minutes and an interval of giving water in the morning from 06:00-06:40, afternoon 13:00-13:10 and afternoon 17:00-17:40 gave significantly different effects on the growth and yield of mustard pakcoy with the highest average plant height was $30.21 \mathrm{~cm}$ and the number of leaves with an average of 14.75 strands and the duration and interval of the efficient drip irrigation system in water use on mustard pakcoy was treatment 3 with a duration of 90 minutes and an interval of giving water in the morning. from 06:00-06:40, afternoon 13:00-13:10 and afternoon 17:00-17:40.
\end{abstract}

Key Words : Crop Water Requirements, Drip Irrigation, Setting The Duration and Interval. 


\section{PENDAHULUAN}

Pemanasan global merupakan suatu peristiwa dimana rata-rata suhu di bumi mengalami kenaikan yang mengakibatkan es di Greenland dan Antartik mencair dan menimbulkan berbagai masalah seperti tenggelamnya pulau-pulau kecil akibat naiknya permukaan air laut, iklim yang tidak menentu, banyaknya organisme dan ekosistem yang rusak serta mempengaruhi ketersediaan air dan pertanian. Menurut Rejekiningrum (2014) Perubahan suhu rerata harian, pola curah hujan, tinggi muka laut, dan variabilitas iklim (misalnya El Nino dan La Nina, Indian Dipole, dan sebagainya) merupakan tanda adanya perubahan iklim yang terjadi di Indonesia. Pemanasan global mengakibatkan 40 tahun mendatang Jawa Tengah akan mengalami kemunduran awal musim hujan di sedangkan akhir musim hujan akan lebih cepat yang berarti lama musim hujan akan semakin pendek. Di beberapa daerah di luar Jawa Tengah akan mengalami peningkatan musim hujan dan penururan lama musim kemarau. Hal ini mengakibatkan pada musim kemarau terjadi peningkatan risiko kekeringan dan pada musim hujan terjadi peningkatan risiko banjir atau bahaya longsor. Negaranegara tropis akan menerima curah hujan yang lebih tinggi tetapi tanah akan mengalami kekeringan (Dadang, 2008).

Cuaca yang susah diprediksi akibat adanya perubahan iklim global dan perubahan pola hujan, dapat meningkatkan ketidakpastian ketersediaan air. Air merupakan salah satu kebutuhan utama dalam bidang pertanian dan penggunaan air secara berlebihan tanpa mempertimbangkan efisiensi penggunaan sumber daya yang tersedia juga dilakukan oleh bidang pertanian. Penyiraman yang biasa dilakukan pada budidaya tanaman umumnya dilakukan tanpa mengukur jumlah air yang diberikan kepada tanaman, sehingga mengakibatkan tanaman memiliki peluang untuk mengalami kekurangan maupun kelebihan air. Ketika tanaman kekurangan air maka tanaman akan mengalami gejala kurus, kerdil hingga mati dan ketika tanaman mengalami kelebihan air maka akan menyebabkan pembusukan akar, juga dapat menggangu proses-proses metabolisme dalam tubuh tanaman. Penyiraman yang dilakukan tanpa takaran juga termaksud dalam pemborosan penggunaan air dikarenakan air yang diberikan tidak sepenuhnya dimanfaatkan oleh tanaman. Ketersediaan sumber air saat ini semakin berkurang akibat dari perubahan iklim yang disebabkan pemanasan global, sehingga diperlukan teknologi yang memungkinkan untuk bisa mengatur pemberian jumlah air pada tanaman yang dengan sesuai kebutuhan tanaman tersebut dan interval penyiraman tanaman yang tepat, sehingga pada musim kemarau ketersediaan air dapat terjaga dan pertumbuhan tanaman juga menjadi optimal.

Salah satu bentuk antisipasi dari dampak perubahan musim yang mempengaruhi ketersediaan air pada musim kemarau yang disebabkan oleh pemanasan global adalah dengan pengaplikasian pemberian air yang tepat waktu dan sesuai kebutuhan air tanaman menggunakan metode irigasi tetes. Irigasi tetes ialah metode pemberian air pada sekitar perakaran tanaman dan permukaan tanah secara langsung secara kontinu dan perlahan. Penggunaan sistem irigasi tetes mengakibatkan efesiensi penggunaan air sebesar $80-95 \%$ (Yanto dkk., 2014). Kelebihan penyiraman menggunakan irigasi tetes ialah dapat mengatur durasi air yang diberikan untuk tanaman sehingga jumlah air yang diberikan pada tanaman akan sesuai 
dengan kebutuhannya sehingga tanaman dapat tumbuh dengan optimal, dan juga dapat mengatur interval penyiraman tanaman dengan sistem otomatisasi menggunakan timer sehingga pertumbuhan dan produktivitas tanaman dapat optimal dan juga tidak membutuhkan tenaga dan waktu yang berlebih hanya untuk melakukan penyiraman pada tanaman.

Tujuan dari penelitain ini ialah untuk mengetahui pengaruh durasi dan jeda sistem irigasi tetes terhadap pertumbuhan dan hasil sawi pakcoy dan untuk mengetahui durasi dan jeda sistem irigasi tetes yang efisien dalam penggunaan air pada tanaman sawi pakcoy.

\section{METODE PENELITIAN}

\subsection{Tempat dan Waktu}

Penelitian ini akan dilakukan di dua tempat yaitu di Kebun Percobaan Kartini Fakultas Pertanian dan Bisnis Universitas Kristen Satya Wacana, alamat Jalan Kartini No. 11, Salatiga sebagai tempat pelaksanaan eksperimen dan di Laboratorium Ilmu Tanah UKSW sebagai tempat melakukan analisis tanah. Penelitian akan dilaksanakan pada bulan juni hingga bulan Agustus 2021.

\subsection{Bahan dan Alat}

Alat yang digunakan adalah ember plastik, trey, polybag $30 \times 30 \mathrm{~cm}$, solder, stopkontak, paralon $1 / 2$ inch, stick dripp, selang PE 7 mm, 6 buah pompa air, timer digital, gergaji, lem stick, korek, 144 pengatur tetesan, T cross \pm 144 buah, timbangan, pipa L dan penutup pipa. Bahan yang digunakan dalam penelitian ini adalah tanah, pupuk kandang, serbuk gergaji, benih sawi, air, pupuk NPK, pestisida dan pupuk kandang.

\subsection{Rancangan Penelitian}

Rancangan percobaan yang digunakan pada penelitian ini adalah rancangan RAK (Rancangan Acak Kelompok). Penelitian ini terdiri dari 6 perlakuan yang akan dicobakan, setiap perlakuan akan diulang sebanyak 4 kali sehingga terdapat 24 unit percobaan.

P1: durasi penyiraman 60 menit dan jeda penyiraman pagi 06:00-06:25, jeda penyiraman siang 13:00-13:15 dan jeda penyiraman sore 17:0017:20

P2: durasi penyiraman 60 menit dan jeda penyiraman pagi 06:00-06:10, jeda penyiraman siang 13:00-13:20 dan jeda penyiraman sore 17:0017:30

P3: durasi penyiraman 90 menit dan jeda penyiraman pagi 06:00-06:40, jeda penyiraman siang 13:00-13:10 dan jeda penyiraman sore 17:0017:40

P4: durasi penyiraman 90 menit dan jeda penyiraman pagi 06:00-06:30, jeda penyiraman siang 13:00-13:30 dan jeda penyiraman sore 17:0017:30

P5: durasi penyiraman 120 menit dan jeda penyiraman pagi 06:00-06:40, jeda penyiraman siang 13:00-13:20 dan jeda penyiraman sore 17:0018:00

P6: durasi penyiraman 120 menit dan jeda penyiraman pagi 06:00-07:00, jeda penyiraman siang 13:00-13:25 dan jeda penyiraman sore 17:00$17: 35$

\subsection{Prosedur Pelaksanaan Peneliitian}

a. Pembuatan instalasi irigasi tetes Water pump yang akan digunakan dimasukan ke dalam water source yang berukuran $30 \mathrm{~L}$ (diameter $40 \mathrm{~cm}$, tinggi $40 \mathrm{~cm}$ ) (gambar 1). Water pump yang digunakan memiliki kapasitas 2000 liter/ jam dengan watt 
38 (gambar 2.). Lalu ke dalam water source dimasukkan air hingga water pump tenggelam

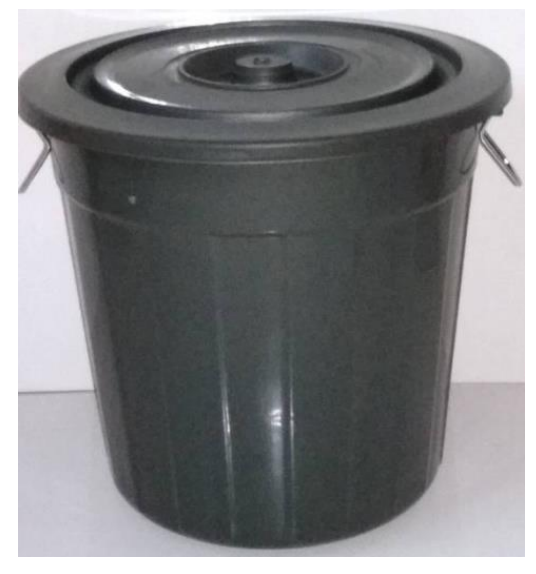

Gambar 3.1. Water source

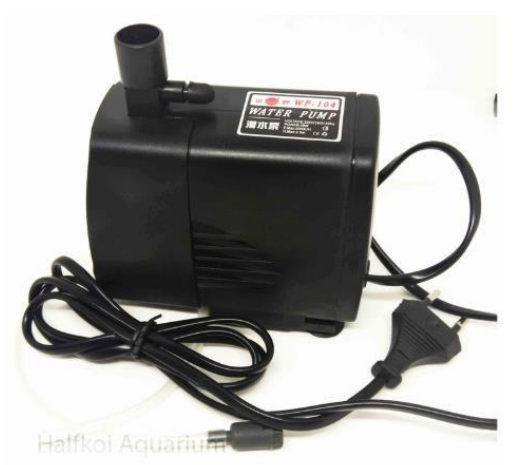

Gambar 3.2 Water pump 
Setelah itu pipa paralon $1 / 2$ inch yang digunakan dilubangi sesuai dengan ukuran selang PE 7 $\mathrm{mm}$, dengan jarak antar lubang ialah $15 \mathrm{~cm}$, dan juga dibuat beberapa lubang besar diantara selang PE untuk memasukkan selang bening 4 $\mathrm{mm}$ yang berfungsi untuk mengurangi tekanan air. Lalu setelah itu PE dimasukkan ke dalam lubang-lubang tersebut, agar selang PE tidak copot atau bocor saat irigasi dinyalakan, maka diberi lem stick disekitar selang bening. Lalu diujung selang bening dimasukkan pengatur tetesan air. Setelah itu instalasi tersebut disambungkan dengan water pump. Dan pengatur tetesan diletakkan pada poliybag yang berisi tanaman.

\section{b. Persemaian bibit sawi pakcoy}

Benih yang digunakan ialah Benih Sawi Takii seed. Benih yang akan digunakan diseleksi dengan merendam benih ke dalam air, benih yang baik akan tenggelam. Penyemaian dilakukan dengan menaruh benih di polybag. Media semai ialah tanah: pupuk kandang dengan perbandingan $2: 1$, kemudian masukan ke dalam polybag. Diletakkan di tempat yang tidak terkena hujan tapi masih terkena sinar matahari. Siram secara teratur, setiap dua hari sekali jika musim cukup baik tapi di musim kemarau 1-2 kali sehari dan beri naungan.

\section{c. Penanaman}

Media tanam menggunakan campuran tanah: pupuk kandang: serbuk gergaji dengan perbandingan 2: 1: 1 . Tempat media tanam yang akan digunakan ialah polybag hitam ukuran 30 x $30 \mathrm{~cm}$. Penanaman dilakukan setelah bibit berusia 2 minggu atau setelah memiliki 4-5 helai daun.

\section{d. Pemeliharaan}

Penyiraman dilakukan sesuai dengan durasi pemberian air dan jeda penyiraman yang telah ditentukan, lalu penyulaman tanaman yang mati dan penyiangan gulma yang tumbuh serta pemupukan dilakukan pada minggu ke 2 dan 4 setelah tanam, dan diberikan disekitar perakaran tanaman, menggunakan pupuk urea yang sesuai kebutuhan tananaman.

\section{e. Panen}

Dalam hal pemanenan penting sekali diperhatikan umur panen dan cara panennya. Umur panen sawi paling lama 70 hari. Paling pendek umur 40 hari. Terlebih dahulu melihat fisik tanaman seperti warna, bentuk dan ukuran daun. Cara panen ada 2 macam yaitu mencabut seluruh tanaman beserta akarnya dan dengan memotong bagian pangkal batang yang berada di atas tanah dengan pisau tajam.

\subsection{Pengamatan}

Pengamatan yang diamati di dalam penelitian ini dibagi menjadi 2 yaitu pengamatan utama dan pengamatan selintas. Pengamatan utama meliputi tingkat tinggi tanaman, jumlah daun, berat brangkasan basah, berat brangkasan kering, evaporasi. Pengamatan selintas meliputi pengukuran kadar air kapasitas lapang, tekstur tanah kandungan klorofil total daun.

Tinggi tanaman $(\mathrm{cm})$

Pengukuran tinggi tanaman dilakukan setiap interval 5 hari saat tanaman berumur 5, 10, 15, 20, 25 dan 30 hari setelah tanam (HST). Pengukuran dilakukan dengan mengukur panjang dari bagian 
pangkal batang hingga ujung daun tertinggi tanaman.

Jumlah Daun (helai)

Perhitungan jumlah daun dilakukan dengan interval 5 hari saat tanaman berumur 5,10 15, 20, 25 dan 30 hari setelah tanam (HST) dihitung mulai dari daun paling bawah sampai daun teratas (pucuk). Penghitungan jumlah daun dilakukan dengan cara menghitung satu per satu daun pada setiap perlakuan.

\section{Kadar klorofil}

Penentuan kadar klorofil dilakukan pada pagi hari seselum tanaman dipanen menggunakan klorofil meter (SPAD).

Pengukuran evaporasi

Evaporasi diukur menggunakan evapotranspirometer piche dan diamati setiap hari.

Berat brangkasan basah Berat brangkasan basah diukur ketika tanaman sudah dipanen, penimbangan dilakukan pada semua bagian tanaman per perlakuan pada timbangan analitik.

\subsection{Analisis Data}

Data analisis dengan metode analisis varian (ANOVA), apabila berbeda nyata maka akan dilanjutkan dengan uji Jarak Berganda Ducan (DMRT). Pengolahan dan analisis data menggunakan Microsoft Excel dan SPSS.

\section{HASIL PENELITIAN DAN PEMBAHASAN}

\subsection{Tinggi Tanaman (cm) dan Jumlah Daun (helai) Tanaman Sawi Pakcoy}

Hasil analisis ragam tinggi tanaman dan jumlah daun tanaman umur 30 hst menunjukkan bahwa durasi dan jeda sistem irigasi tetes memberi pengaruh yang sangat berbeda nyata terhadap tinggi tanaman dan jumlah daun. Hasil uji DMRT tinggi tanaman dan jumlah daun disajikan pada (tabel 1.)

Tabel 1. Rerata Tinggi Tanaman (cm) dan Jumlah Daun (cm) Sawi Pakcoy Hari Ke- 30 Hst

\begin{tabular}{|c|c|c|c|c|c|c|}
\hline \multirow{2}{*}{ KODE } & \multicolumn{3}{|c|}{ Perlakuan } & \multirow{2}{*}{$\begin{array}{l}\text { Total menit } \\
\text { per hari }\end{array}$} & \multirow{2}{*}{$\begin{array}{l}\text { Tinggi } \\
\text { Tanaman } \\
(\mathrm{cm})\end{array}$} & \multirow{2}{*}{$\begin{array}{l}\text { Jumlah } \\
\text { daun } \\
\text { (helai) }\end{array}$} \\
\hline & Pagi & siang (menit) & Sore (menit) & & & \\
\hline \multirow[t]{2}{*}{$\mathrm{P} 1$} & 25 & 15 & 20 & & \multirow{2}{*}{$26,51 \mathrm{a}$} & \multirow{2}{*}{$12,75 a$} \\
\hline & $06: 00-06: 25$ & $13: 00-13: 15$ & $17: 00-17: 20$ & & & \\
\hline \multirow[t]{2}{*}{$\mathrm{P} 2$} & 10 & 20 & 30 & 00 & \multirow{2}{*}{$26,29 a$} & \multirow{2}{*}{$12,18 \mathrm{a}$} \\
\hline & 06:00-06:10 & $13: 00-13: 20$ & $17: 00-17: 30$ & & & \\
\hline \multirow[t]{2}{*}{ P3 } & 40 & 10 & 40 & & \multirow{2}{*}{$30,21 b$} & \multirow{3}{*}{$14,75 b$} \\
\hline & $06: 00-06: 40$ & $13: 00-13: 10$ & $17: 00-17: 40$ & 90 & & \\
\hline \multirow[t]{2}{*}{$\mathrm{P} 4$} & 30 & 30 & 30 & 90 & \multirow{2}{*}{$26,75 a$} & \\
\hline & $06: 00-06: 30$ & $13: 00-13: 30$ & $17: 00-17: 30$ & & & $13,39 a$ \\
\hline \multirow[t]{2}{*}{ P5 } & 40 & 20 & 60 & & \multirow{2}{*}{$25,49 a$} & \multirow{2}{*}{$12,45 \mathrm{a}$} \\
\hline & $06: 00-06: 40$ & 13:00-13:20 & 17:00-18:00 & 120 & & \\
\hline \multirow[t]{2}{*}{ P6 } & 60 & 25 & 35 & & \multirow{2}{*}{$25,52 \mathrm{a}$} & \multirow{2}{*}{$11,89 \mathrm{a}$} \\
\hline & 06:00-07:00 & $13: 00-13: 25$ & $17: 00-17: 35$ & & & \\
\hline
\end{tabular}

Keterangan: Angka yang diikuti oleh huruf kecil yang sama menunjukkan tidak berbeda nyata menurut uji lanjut DMRT pada taraf $5 \%$. 
Hasil uji DMRT (tabel 1.) menunjukkan bahwa rerata tinggi dan jumlah daun pada perlakuan 1, perlakuan 2 , perlakuan 4 , perlakuan 5 dan perlakuan 6 memberikan pengaruh yang tidak berbeda nyata terhadap tinggi tanaman dan jumlah daun, sedangkan rerata tinggi tanaman dan jumlah daun pada perlakuan 3 memberikan pengaruh nyata yang lebih tinggi dibandingkan dengan perlakuan lainnya yaitu $30,21 \mathrm{~cm}$ untuk tinggi tanaman dan 14,75 untuk jumlah daun.

\subsection{Berat Brangkasan Basah dan Kandungan Klorofil Total Tanaman sawi Pakcoy}

Hasil analisis ragam berat brangksan basah dan klorofil total tanaman sawi menunjukkan bahwa durasi dan jeda sistem irigasi tetes memberi pengaruh yang sangat berbeda nyata terhadap berat brangkasan basah dan klorofil total. Hasil uji DMRT berat brangkasan basah dan klorofil total disajikan pada (tabel 2.). Hasil uji DMRT (tabel 2.) menunjukkan bahwa berat brangkasan basah pada perlakuan 1, perlakuan 2, perlakuan 4, perlakuan 5 dan perlakuan 6 memberikan pengaruh yang tidak berbeda nyata terhadap brangkasan basah dan klorofil, sedangkan rerata berat brangkasan basah tanaman dan klorofil pada perlakuan 3 memberikan pengaruh nyata yang lebih tinggi dibandingkan dengan perlakuan lainnya yaitu $30,50 \mathrm{gr}$ untuk berat brangksan basah dan 46,33 $\mu \mathrm{g} / \mathrm{m}$ untuk klorofil total tanaman.

Tabel 2. Berat Brangkasan Basah dan Kandungan Klorofil Total Tanaman sawi Pakcoy

\begin{tabular}{|c|c|c|c|c|c|c|}
\hline \multirow{2}{*}{ KODE } & \multicolumn{3}{|c|}{ Perlakuan } & \multirow{2}{*}{$\begin{array}{l}\text { Total } \\
\text { menit per } \\
\text { hari }\end{array}$} & \multirow{2}{*}{$\begin{array}{l}\text { Berat } \\
\text { Brangkasan } \\
\text { Basah (gr) }\end{array}$} & \multirow{2}{*}{$\begin{array}{l}\text { Klorofil total } \\
(\mu \mathrm{g} / \mathrm{m})\end{array}$} \\
\hline & Pagi (menit) & siang (menit) & Sore (menit) & & & \\
\hline $\mathrm{P} 1$ & $\begin{array}{l}25 \\
(06: 00-06: 25)\end{array}$ & $\begin{array}{l}15 \\
(13: 00-13: 15)\end{array}$ & $\begin{array}{l}20 \\
(17: 00-17: 20)\end{array}$ & \multirow{2}{*}{60} & $25,72 \mathrm{a}$ & $38,80 \mathrm{a}$ \\
\hline $\mathrm{P} 2$ & $\begin{array}{l}10 \\
(06: 00-06: 10)\end{array}$ & $\begin{array}{l}20 \\
(13: 00-13: 20)\end{array}$ & $\begin{array}{l}0 \\
17: 00-17: 30)\end{array}$ & & $26,04 \mathrm{a}$ & $38,15 \mathrm{a}$ \\
\hline P3 & $\begin{array}{l}40 \\
(06: 00-06: 40)\end{array}$ & $\begin{array}{l}10 \\
(13: 00-13: 10)\end{array}$ & $\begin{array}{l}0 \\
17: 00-17: 40)\end{array}$ & \multirow{2}{*}{90} & $30,50 \mathrm{~b}$ & $46,33 b$ \\
\hline $\mathrm{P} 4$ & $\begin{array}{l}30 \\
(06: 00-06: 30)\end{array}$ & $\begin{array}{l}30 \\
(13: 00-13: 30)\end{array}$ & $\begin{array}{l}0 \\
17: 00-17: 30)\end{array}$ & & $28,76 \mathrm{a}$ & $39,60 \mathrm{a}$ \\
\hline P5 & $\begin{array}{l}40 \\
(06: 00-06: 40)\end{array}$ & $\begin{array}{l}20 \\
(13: 00-13: 20)\end{array}$ & $\begin{array}{l}0 \\
17: 00-18: 00)\end{array}$ & \multirow{2}{*}{120} & $26,94 \mathrm{a}$ & $38,80 \mathrm{a}$ \\
\hline P6 & $\begin{array}{l}60 \\
(06: 00-07: 00)\end{array}$ & $\begin{array}{l}25 \\
(13: 00-13: 25)\end{array}$ & $\begin{array}{l}5 \\
17: 00-17: 35)\end{array}$ & & 26,95 a & 38,15 a \\
\hline
\end{tabular}

Keterangan: Angka yang diikuti oleh huruf kecil yang sama menunjukkan tidak berbeda nyata menurut uji lanjut DMRT pada taraf $5 \%$.

Pertumbuhan tanaman yang lebih baik pada perlakuan 3 dibandingkan perlakuan 1 dan perlakuan 2, diduga karena pemberian air pada perlakuan 1 dan perlakuan 2 kurang optimal untuk digunakan tanaman dalam pertumbuhan dan produktivitasnya. Kekurangan air yang terjadi pada tanaman akan menyebabkan penurunan laju fotosintesis dan respirasi sehingga menyebabkan energi yang dibutuhkan untuk pertumbuhan menurun sehingga pembelahan maupun pembentangan sel untuk memperbesar organpun ikut menurun yang mengakibatkan organ tumbuhan atau morfologi yang terbentuk 
yaitu daun, batang menjadi lebih kecil sehingga menurunkan produktivitas tanaman. Hal ini sesuai dengan pernyataan Rezky (2018) menurutnya ketersediaan air yang cukup, berguna untuk proses fotosintesis agar dapat berjalan lancar, sehingga pemanjangan, pembelahan dan differensiasi sel akan menjadi lebih baik yang dapat mendorong pertumbuhan tinggi tanaman dan jumlah daun. Selain menurunkan pertumbuhan tinggi tanaman dan jumlah daun tanaman, kekurangan air juga akan menurunkan berat brangkasan basah dan berat brangkasan kering. Hal ini dikarenakan kekurangan air juga dapat mengakibatkan berkurangnya pula ketersediaan hara bagi tanaman, karena menurut Mapegau, (2006) jumlah air dalam tanah yang rendah dapat mengakibatkan rendahnya konsentrasi hara dalam larutan tanah dan laju pergerakan hara ke akar melalui difusi dan transport massa. Dimana berat brangkasan basah dipengaruhi oleh proses fotosintesis yang dilakukan oleh tanaman dan unsur hara yang diserap oleh tanaman, kekurangan air dapat menurunkan laju proses fotosintesis dan penurunan penyerapan unsur hara oleh tanaman yang juga akan mengakibatkan penurunan berat brangkasan basah. Menurut Guritno, (1995) semua bagian tanaman yang secara kasar berasal dari hasil fotosintesis dan serapan unsur hara merupakan berat segar tanaman Selain itu rendahnya kandungan klorofil total pada perlakuan 1 dan perlakuan 2 dibandingkan dengan perlakuan 3 diduga karena kekurangan air pada tanaman, dikarenakan pemberian air yang kurang optimal dimana banyaknya air yang diserap oleh akar tanaman sangat bergantung pada ketersediaan air pada Hal ini sesuai dengan pernyataan Wardhani (2015) menurutnya kondisi hipoksia (oksigen sedikit) pada media tanam, akan meningkatkan sintesis ABA tanah atau media tanam. Kekurangan air akan mempengaruhi sintesis klorofil pada daun. Dimana Menurut Nurjanaty dkk, (2019) ketersediaan air akan mempengaruhi terlarutnya unsur hara yang dibutuhkan tanaman dalam media tanam. Kurangnya ketersediaan air akan menyebabkan penurunan konsentrasi klorofil dikarenakan penyerapan unsur hara terhambat, sehingga mempengaruhi ketersediaan unsur Nitrogen dan Magnesium yang berperan dalam sintesis klorofil.

Pertumbuhan tanaman pada perlakuan 3 yang lebih baik dari pada perlakuan 5 dan perlakuan 6 dikarenakan kelebihan air yang diberikan pada perlakuan 5 dan perlakuan 6 berdampak pada jenuhnya tanah dan terjadinya pencucian unsur hara yang ada pada media tanam. Menurut Hanafiah (2005) saat kondisi tanah jenuh air, ruang pori tanah akan banyak diisi oleh air yang bergerak relative cepat sehingga dapat mencui unsur-unsur hara yang dilaluinya dan kelebihan air pada tanah akan menganggu absorbi unsur hara oleh tanaman. Kejenuhan media tanam yang terjadi pada perlakuan 5 dan perlakuan 6 mengakibatkan media tanam mengalami kekurangan oksigen dan berdampak pada pertumbuhan tanaman khususnya pada tinggi tanaman. Hal ini dikarenakan pori tanah yang seharusnya diisi oleh oksigen berkurang karena pori tanah untuk oksigen telah diisi oleh kelebihan air yang diberikan pada tanah. Cekaman kelebihan air yang terjadi juga akan meningkatkan pengaruh hormon ABA (asam absisat) yang adalah inhibitor dari sintesis hormon auksin dan sitokinin yang menyebakan terhambatnya proses pemanjangan sel dan pembelahan sel.

(asam absisat), ABA (asam absisat) mampu menghambat pemanjangan batang (tinggi tanaman). Selain itu kondisi jenuh air yang dialami pada 
media tanaman juga akan mengakibatkan fiksasi $\mathrm{K}$ oleh tanah menjadi lemah sehingga unsur hara $\mathrm{K}$ pada media tanam menjadi rendah, sedangkan pencucian unsur hara akibat kelebihan air mengakibatkan beberapa unsur hara yang berperan penting dalam pertumbuhan dan hasil tanaman akan hilang akibat pencucian tersebut. Salah satu unsur hara yang mobil dalam tanah dan larut dalam air dan memiliki peranan penting dalam pertumbuhan dan hasil tanaman ialah unsur Nitrogen $(\mathrm{N})$. Menurut Lakitan (2011) Unsur NPK berperan dalam merangsang proses fisiologi dalam pertambahan tinggi tanaman. Proses fisiologi tanaman dimana sel melakukan pembelahan yang mengakibatkan pertambahan tinggi tanaman.

Kelebihan air yang terjadi pada perlakuan 5 dan perlakuan 6 juga mengakibatkan rendahnya berat brangkasan basah dibandingkan dengan perlakuan 3. Hal ini dikarenakan kelebihan air yang diberikan pada perlakuan tersebut, mengakibatkan media tanam menjadi jenuh air, dimana keadaan tersebut mengakibatkan kurangnya oksigen pada daerah perakaran sehingga mengakibatkan terganggunya penyerapan unsur hara. Kelebihan air juga akan membuat terjadinya pencucian unsur hara pada media tanaman. Hal inilah yang mengakibatkan rendahnya berat brangkasan basah pada perlakuan 5 dan perlakuan 6 dikarenakan adanya hubungan antara unsur hara dengan berat brangsakan basah. Pencucian unsur hara yang terjadi mengakibatkan ketersediaan unsur hara juga berkurang. Menurut Hulhudi dkk (2015) peningkatan hasil berat basah tanaman dapat mencapai hasil yang optimal saat tanaman memperoleh unsur hara yang dibutuhkan sehingga terjadi peningkatan jumlah maupun ukuran sel dapat mencapai optimal. Kurangnya penyerapan hara oleh akar dikarenakan kejenuhan pada media tanam dan hilangnya unsur hara akibat pencucian yang diakibatkan oleh kelebihan air inilah yang mengakibatkan rendahnya berat brangkasan basah juga akan mempengaruhi kandungan klorofil tanaman. Hal ini dikarenakan tanaman tidak dapat menyerap dan memanfaatkan unsur hara yang berperan penting dalam sintesis klorofil secara optimal. Unsur hara Nitrogen $(\mathrm{N})$ merupakan unsur yang berperan dalam pembentukkan klorofil dan salah satu unsur hara yang mudah larut dan hilang. Menurut Tisdale dkk (1999 lihat dalam Primanti \& Oteng, 2005), N merupakan unsur yang mobil dalam tanah dan larut dalam air, sehingga dengan pemberian air yang berlebihan pencucian $\mathrm{N}$ dapat terjadi. Diketahui bahwa beberapa unsur hara (Nitrogen dan Magnesium) memiliki peran dalam peningkatan konsentrasi klorofil pada daun.

Dari 3 durasi pemberian air irigasi tetes yang diberikan, perlakuan terbaik ialah perlakuan durasi 90 menit dikarenakan durasi perlakuan tersebut menyediakan kebutuhan air optimal untuk tanaman sawi. Menurut Muzayyanah (2009) kebutuhan air untuk pertumbuhan tanaman sawi pada media tanah liat, serbuk gergaji dan pasir ialah 0,275 liter/tanaman/hari, dari perhitungan yang telah dilakukan dengan pengaturan tetesan 60 tetes/menit maka 0,275 liter dapat dihasilkan dengan pengaturan penyiraman 86 menit yang dibulatkan menjadi 90 menit. Dari perlakuan yang dilakukan terdapat 2 durasi penyiraman 90 menit yaitu perlakuan 3 dan 4 namun perlakuan terbaik dihasilkan oleh perlakuan 3. Pertumbuhan tanaman lebih baik pada perlakuan 3 dari pada perlakuan 4, padahal volume air yang diberikan per hari sama, diduga bahwa jeda pemberian air berdampak positif pada perlakuan 3. Pemberian air yang bertahap dalam jumlah dan waktu yang memang dibutuhkan tanaman akan 
meningkatkan pertumbuhan tanaman tersebut.

Pada tabel 4.1 dapat dilihat bahwa jeda pemberian air pada pagi hari antara perlakuan 3 dan perlakuan 4 berbeda. Dimana jeda pemberian air pada perlakuan 3 ialah jam 06:00- 06:40 sedangkan jeda pemberian air pada perlakuan 4 ialah jam 06:00-06:30. Dari data tersebut dapat diketahui bahwa pemberian air dengan volume terbanyak saat pagi hari diberikan oleh perlakuan 3 . Diduga hal tersebutlah yang mengakibatkan pertumbuhan tanaman pada perlakuan 3 lebih baik dibandingkan dengan perlakuan 4, dikarenakan pemberian air yang optimal pada pagi hari akan dimanfaatkan tanaman untuk proses fotosintesis dan transpirasi tanaman pada siang hari. Proses fotosintesis dan transpirasi merupakan proses metabolisme yang mempengaruhi pertumbuhan dan perkembangan tanaman tersebut. Ketersediaan air yang optimal pada media tanam secara tidak langsung menyediakan air yang banyak untuk proses fotosintesis tanaman. Menurut Marjenah (2010) ketersediaan air dalam jumlah yang cukup atau sesuai dengan kebutuhan tanaman dalam metabolismenya dapat meningkatkan aktivitas tanaman. Metabolisme tersebut ialah proses fotosintesis yang berkaitan dengan tinggi tanam, yang mana meningkatnya tinggi tanaman juga akan meningkatkan jumlah daun oleh tanaman. Hal inilah yang diduga menyebabkan tinggi tanaman dan jumlah daun perlakuan 3 lebih baik dibandingkan dengan perlakuan 4, diduga jeda pemberian air perlakuan 4 pada pagi hari selama 30 menit tidak mampu menyediakan air optimum untuk proses fotosintesis. Air yang tersedia tersebut juga akan melarutkan unsur hara pada media tanam sehingga dapat diserap oleh akar dan akan disebarkan ke seluruh bagian tanaman yang membutuhkan sehingga akan meningkatkan prosesproses metabolisme tanaman. Menurut Wardhani (2015) peran unsur Nitrogen (N) bagi tanaman ialah sebagai pembentukan klorofil pada daun. Klorofil tersebut berguna dalam proses fotosintesis, sehingga ketika ketersediaan air optimal pada media tanam juga akan meningkatkan kandungan klorofil total pada tanaman, karena penyerapan unsur hara khususnya unsur hara Nitrogen $(\mathrm{N})$ tidak terganggu oleh cekanam air (kelebihan atau kekurangan). Hal inilah yang diduga menyebabkan kandungan klorofil total pada perlakuan 3 lebih baik dari pada perlakuan 4. Proses fotosintesis yang berlangsung baik, diikuti oleh ketersediaan hara dan penyerapan hara yang optimal oleh tanaman akan berdampak pada peningkatan berat brangkasan basah. Hal ini sesuai dengan pernyataan menurut Ahmad dkk, (2016) biomassa tanaman yang maksimal menunjukkan bahwa fotosintesis pada tanaman berjalan baik sehingga energi yang dihasilkan dari proses tersebut dipakai oleh tanaman untuk pertumbuhan.

Kurangnya jumlah air saat proses transpirasi terjadi juga akan mempengaruhi produktivitas tanaman dikarenakan ketika proses transpirasi berlangsung akan menyebabkan peningkatan laju pengangkutan unsur hara melalui pembuluh xylem, yang mana unsur hara merupakan salah satu faktor penting yang mempengaruhi dan menunjang pertumbuhan dan hasil tanaman. Dimana menurut Marjenah (2010) penurunan ketersediaan air tanaman akan menghambat beberapa proses metabolisme tanaman. Proses yang pertama kali terhambat adalah transpirasi, lalu fotosintesis, kemudian respirasi serta proses-proses lainnya. Namun meskipun air dibutuhkan untuk proses transpirasi pada siang hari, ketersediaan air yang berlebihan saat 
proses transpirasi terjadi akan mengakibatkan tanaman mengalami proses peningkatan transpirasi yang berlebihan dan mengakibatkan kerugian pada tanaman. Dimana menurut Marjenah (2010) semakin besar kandungan air tanah mengakibatkan semakin besar pula transpirasi yang terjadi pada daun dan menurut Lukitasari (2016) Kenaikan absorpsi air dalam tanah yang berlebih sebagai akibat kenaikan tranpirasi bisa berakibat peningkatan absorpsi garam-garam dalam tanah sedemikian rupa sehingga tanaman bisa keracunan.

Pada tabel 4.1 dapat dilihat bahwa jeda pemberian air pada siang hari antara perlakuan 3 dan perlakuan 4 berbeda. Dimana jeda pemberian air pada perlakuan 3 ialah jam 13:00-13:10 sedangkan jeda pemberian air pada perlakuan 4 ialah jam 13:00-03:30. Dari data tersebut dapat diketahui bahwa pemberian air dengan volume terbanyak pada siang hari diberikan pada perlakuan 4. Banyaknya jumlah air yang diberikan pada siang hari pada perlakuan 4 diduga mengakibatkan jumlah air yang tersedia tidak lagi sesuai dengan kebutuhan optimal tanaman sawi yaitu 0,275liter yang bisa dipenuhi dengan pemberian air selama 90 menit. Ketersediaan air yang kurang optimal pada perlakuan 4 dikarenakan kemungkinan pemberian air siang tidak masuk seluruhnya ke dalam media tanaman karena menguap akibat proses evaporasi bisa mengakibatkan terganggunya perkembangan akar, karena media tanam kekurangan air, sehingga juga akan menurunkan laju penyerapan air dan unsur hara yang merupakan penunjang untuk pertumbuhan dan produktivitas tanaman. Hal ini sesuai dengan pernyataan Kurniawan (2017), menurutnya rendahnya jumlah air pada media tanam akan berimbas pada terhambatnya perkembangan akar tanaman sehingga penyerapan air dan unsur hara oleh akar tanaman terganggu. Pada siang hari suhu dan kelembapan harian meningkat, sehingga air yang diberikan akan hilang sebagian atau seluruhnya akibat proses evaporasi. Dimana rata-rata suhu pada saat penanaman ialah $33,8^{\circ} \mathrm{C}$ yang terbilang cukup panas dengan kelembapan 46,3\%, sehingga semakin banyak volume air yang diberikan pada siang semakin besar kemungkinan air yang diberikan tidak tersedia didalam media tanam dan tidak dimanfaatkan tanaman.

Pada saat penanaman rata-rata suhu ialah $33,8^{\circ} \mathrm{C}$ yang terbilang cukup panas dengan kelembapan $46,3 \%$ akan mengakibatkan tingginya proses transpirasi yang terjadi pada tanaman, sehingga perlu dilakukan penyiraman kembali pada sore hari untuk pemulihan tanaman. Menurut Darmawan dkk (2010) pada hari yang cerah, suhu harian tertinggi terjadi pada pukul 15:00. Pemberian air pada sore hari digunakan untuk memulihkan turgor sel yang sempat turun akibat laju transpirasi air yang tinggi. Air yang disiapkan diserap oleh tanaman pada malam hari untuk menggantikan air yang telah hilang pada saat proses transpirasi sore hari pada pukul 15:00, sehingga ketika laju transpirasi meningkat namun tidak diimbangi dengan ketersediaan air yang optimal pada sore hari maka akan menyebabkan tanaman kekurangan air. Hal inilah yang mengakibatkan pertumbuhan tanaman pada perlakuan 3 lebih baik dari pada perlakuan 4 dikarenakan perbedaan jeda pemberian air yaitu pada perlakuan 3 dari jam 06:0006:40 sedangkan jeda pemberian air pada perlakuan 4 ialah dari jam 06:00-06:30. Pemberian air yang lebih banyak pada perlakuan 3 selama 40 menit pada sore hari diduga mampu memulihkan turgor sel tanaman yang sempat berkurang dikarenakan proses transpirasi yang terjadi. Proses evapotranspirasi yang 
terjadi pada siang hari akan mengakibatkan konsentrasi air tanah menurun begitupun konsentrasi larutan jaringan tanaman sehingga, ketika penyiraman sore dilakukan maka akan menambah konsentrasi larutan air dalam tanah sehingga akan terjadi penyerapan air oleh tanaman, jadi semakin banyak air yang diberikan pada penyiraman sore hari semakin banyak pula air yang akan diserap tanaman sebagai tindakan pemulihan. Menurut Lukitasari (2016) penyerapan air oleh akar tanaman sangat dipengaruhi oleh konsentrasi larutan tanah. Apabila tekanan difusi air di luar akar lebih kecil (konsentrasi air besar) daripada tekanan air dalam jaringan akar (konsentrasi air kecil), maka akan terjadi aliran air dari larutan tanah ke dalam jaringan akar tanaman. Namun ketika proses transpirasi pada siang hari menguapkan banyak air dan tidak diimbangi dengan ketersedian air yang banyak atau dengan kata lain penguapan air pada tanah dan jaringan tanaman lebih besar dari pada pemasukkan air maka tanaman akan mengalami layu sementara.

Menurut Arsyad, (2010) efisiensi penggunaan air pada lahan pertanian dapat didefinisikan sebagai jumlah produksi tanaman (biomassa) per satuan air yang digunakan selama satu musim tanam. Untuk efisiensi penggunaan air pada penelitian ini ialah ketika durasi dan jeda sistem irigasi tetes yang diberikan sesuai dengan kebutuhan tanaman dan dapat meningkatkan pertumbuhan dan hasil tanaman pakcoy. Pemberian air pada penelitian ini dilakukan dengan sistem irigasi tetes. Pemberian air menggunakan metode irigasi tetes juga akan meningkatkan efisiensi penggunaan air. Menurut Yanto dkk, (2014) Penggunaan sistem irigasi tetes mengakibatkan efesiensi penggunaan air sebesar 80-95 $\%$. Pemberian air pada penelitian ini diatur, dimana dalam 1 menit tetesan yang dihasilkan ialah 60 tetes, sehingga jumlah air yang diberikan pada masing-masing perlakuan diketahui. Menurut Muzayyanah (2009) kebutuhan air untuk pertumbuhan tanaman sawi pada media tanah liat, serbuk gergaji dan pasir ialah 0,275 liter/tanaman/hari. Kebutuhan air pada tanaman sawi jika diberikan dengan metode irigasi tetes ialah selama 86 menit. Dari perlakuan yang dilakukan perlakuan 3 dan 4 lah yang memiliki durasi pemberian air sesuai kebutuhan air tanaman sawi yaitu 90 menit. Dimana durasi pemberian air yang dilakukan pada perlakuan 3 ialah 90 menit yang setara dengan perlakuan 4 namun berbeda durasi pemberian setiap sesi pada penyiraman pagi, siang dan sore. Perbedaan sesi durasi penyiraman inilah yang mengakibatkan perbedaan hasil pertumbuhan pada masing-masing perlakuan. Pada sesi penyiraman yang dilakukan pada siang hari, durasi pemberian air yang tersingkat diberikan pada perlakuan 3 selama 10 menit (32 $\mathrm{ml}$ ), lalu perlakuan 1 selama15 menit (48 $\mathrm{ml}$ ), perlakuan 2 dan perlakuan 5 selama 20 menit $(64 \mathrm{ml})$, perlakuan 6 selama 25 menit $(80 \mathrm{ml})$ dan perlakuan 4 selama 30 menit $(96 \mathrm{ml})$. Semakin banyaknya pemberian air yang dilakukan pada siang hari semakin menurun pula tingkat dalam efisiensi penggunaan air dikarenakan air yang diberi tidak akan masuk sepenuhnya kedalam media tanam namun hilang akibat proses evaporasi, dimana rata-rata suhu selama penanaman yang cukup tinggi yaitu $33,8^{\circ} \mathrm{C}$ dengan kelembapan 46,3\%. Menurut Mawardi dkk, (2008) Penyiraman yang dilakukan pada siang hari akan mengakibatkan air yang diberikan tidak terserap oleh tanaman karena air yang diberikan mengalami penguapan karena suhu udara pada siang hari umumnya lebih besar. Kelembaban udara pada siang hari relatif lebih rendah. Efisiensi penggunaan air terbaik dimiliki oleh perlakuan 3 yang dapat meningkatkan produktivitas tanaman. 


\section{KESIMPULAN}

Durasi dan jeda sistem irigasi tetes berpengaruh sangat nyata terhadap pertumbuhan tanaman sawi pakcoy baik dalam tinggi tanaman, jumlah daun dan hasil tanaman sawi pakcoy

Durasi dan jeda sistem irigasi tetes yang efisien dalam penggunaan air pada tanaman sawi pakcoy ialah perlakuan 3 dengan durasi pemberian air 90 menit dengan sesi penyiraman pagi 40 menit, siang 10 menit dan sore 40 menit.

\section{DAFTAR PUSTAKA}

Ahmad, F., Fathurrahman., \& Bahrudin. (2016). Pengaruh Media dan Interval Pemupukan terhadap Pertumbuhan Vigor Cengkeh (Syzygum aromaticum L.). E-Jurnal Mitra Sains, 4(4), 36-47.

Arsyad, S. (2010). Konservasi Tanah Dan Air. Bogor: Penerbit IPB (IPB Press).

Dadang, Rusbiantoro. (2008). Global Warning for Beginner. Pengantar Kompehensif Tentang Pemanasan Global. Yogyakarta: Penembahan.

Darmawan., Januar., \& J. S. Baharsjah. (2010). Dasar- Dasar Fisiologi Tanaman. Bogor: Penerbit Sitc.

Guritno. B. (1995). Pertumbuhan Tanaman. Yogyakarta: UGM Press.

Hanafiah, K. A. (2005). Dasar-Dasar Ilmu Tanah. Jakarta: Rajawali Pers.

Hulhudi, D. M., Wawan, P., \& Fauzan, Z. (2015). Pertumbuhan dan Hasil Tanaman Sawi (Brasicca juncea L.) Berdasarkan Area dan Waktu Pemberian Pupuk Organik Cair R2F2 di Desa Jatimulya Kabupaten Boalemo. Jurnal Agroteknotropika, 4(3), $250-255$
Kurniawan, D., Chairani, H., \& Lutfi, A. M. S. (2017). Morfofisiologi Akar Melalui Interval Penyiraman, Pemberian Mikoriza dan Modifikasi Media Tanam pada Pembibitan Kakao (Theobroma cacao L.). Jurnal Pertanian Tropik, 4(3), 209218209

Lukitasari. M. (2016). Ekologi Tumbuhan. Diktat Kuliah. Madiun: IKIP PGRI Press.

Lakitan. (2011). Dasar-Dasar Fisiologi Tumbuhan. Jakarta: PT. Raja Grafindo Persada.

Marjenah. (2010). Pengaruh Kandungan Air Tanah Terhadap Pertumbuhan dan Transpirasi Semai Shoreo Leproslilo Miq. Jurnal Penelitian Olpterokarpa, 4(1), 11-24

Mapegau. (2006). Pengaruh Cekaman Air Terhadap Pertumbuhan dan Hasil Tanaman Kedelai. Jurnal Ilmiah Pertanian Kultura, 41(1), 43-48

Mawardi., Ikhwanuddin., \& Sudaryono. (2008). Pengaruh Irigasi dan Naungan terhadap Produksi Tanaman Cabe (Capsicum annum) pada Lahan Berpasir di Pantai Glagah, Yogyakarta. J. Hidrosfir Indonesia, 3(1), 41-49

Muzayyanah. (2009). Pengaruh Pemberian Pupuk Bokashi Terhadap Pertumbuhan Tanaman Sawi (Branssica Juncea L.) Skripsi. Program Studi Biologi. Universitas Islam Negeri Maulana Malik Ibrahim Malang. Malang.

Nurjanaty, N., R. Linda., \& Mukarlina. (2019). Pengaruh Cekaman Air dan Pemberian Pupuk Daun terhadap Pertumbuhan Tanaman Sawi (Brassica Juncea L.). Protobiont, 8(3), $6-11$

Primanti., I. S \& Oteng, H. (2005). Potensi Pencucian Pupuk Majemuk Phonska 
serta Pengaruhnya terhadap Pertumbuhan dan Produksi Bayam (Amaranthus tricolor. L) pada Latosol dengan Kandungan Liat yang Berbeda. Jurnal Tanah dan Lingkungan, 7(1), 22-26

Rejekiningrum, P. (2014). Dampak Perubahan Iklim terhadap Sumberdaya Air: Identifikasi, Simulasi, dan Rencana Aksi. Jurnal Sumberdaya Lahan, 8(1), 1- 15.

Rezky, F. L. (2018). Pengaruh Jumlah Pemberian Air dengan Sistem Irigasi Tetes terhadap Pertumbuhan dan Hasil Tanaman Terung Ungu
(Solanum melongena L.). Jurnal Agrohita, 2(2), 10-19

Wardhani, S. P. (2015). Pengaruh Genangan Air Terhadap Morfologi dan Anatomi Beberapa Varietas Tanaman Tembakau (Nicotiana tabacum L.). Skripsi. Program Studi Biologi. Institut Teknologi Sepuluh Nopember. Surabaya.

Yanto, Hendri., A. Tusi \& Sugeng, T. (2014). Aplikasi Sistem Irigasi Tetes Pada Tanaman Kembang Kol (Brassica Oleracea Var. Botrytis L. Subvar. Cauliflora Dc) dalam Greenhouse. Jurnal Teknik Pertanian Lampung, 3(2), 141-154. 